\title{
Determination of shoreline change along the East-Java coast, using Digital Shoreline Analysis System
}

\author{
Eva Louise den Boer ${ }^{1, *}$, Suntoyo ${ }^{2}$, and $A C$ Oele $^{3}$ \\ ${ }^{1}$ Student, Delta Academy, HZ University of Applied Sciences, Vlissingen, the Netherlands. \\ Research Intern, Ocean Engineering Department, Faculty of Marine Technology, Institut Teknologi \\ Sepuluh Nopember (ITS), Surabaya, Indonesia (60111). \\ 2 Associate Professor, Ocean Engineering Department, Faculty of Marine Technology, Institut \\ Teknologi Sepuluh Nopember (ITS), Surabaya, Indonesia (60111). \\ ${ }^{3}$ Associate Professor, Delta Academy, HZ University of Applied Sciences, Vlissingen, the \\ Netherlands.
}

\begin{abstract}
This study focused on determining the shoreline change at the East- Java coast by comparing the shorelines between 2006 and 2015, using digital shoreline analysis system (DSAS) techniques to identify and measure erosion (shoreline retreat) and accretion (shoreline advance). Shoreline change rates are calculated according to Shoreline Change Envelope (SCE), Net Shoreline Movement (NSM), End Point Rate (EPR), and Linear Regression Rate (LRR). Results present local variations in shoreline change distance as well as in shoreline change rates. The statistical methods showed similarities with the highest accretion distance of 991.57 meters in the region of Mulyorejo and highest erosion distance of 928.75 meters in Sidoarjo. The EPR shows a rate with a maximum of $169.98 \mathrm{~m} /$ year and a minimum of $3.428 \mathrm{~m} /$ year. As for the LRR a maximum of $189.58 \mathrm{~m} /$ year and a minimum of $5.467 \mathrm{~m} /$ year were conducted from calculations.
\end{abstract}

\section{Introduction}

A key requirement for effective coastal zone management is the analysis of changes in the past. Although changes along the coast over the coming century cannot be predicted simply by assuming the past trend will continue, it can contribute by constructing the basic knowledge used in future prediction formulas or models [1]. With a total length in coastline of $81000 \mathrm{~km}$ spread over 17508 islands, research in coastal development is valuable for disaster risk reduction and coastal management in the archipelagic country of Indonesia [2].

Located along the East Java Coast, the study area covers the areas of Pamurbaya and Sidoarjo. Geographically the districts are situated between $7^{\circ} 24^{\prime}$ South Latitude - $112^{\circ} 80^{\prime}$ East Longitude and $7^{\circ} 48^{\prime}$ South Latitude $-112^{\circ} 83^{\prime}$ East Longitude. The region is known

\footnotetext{
* Corresponding author: Eva.denboer@hotmail.com
} 
for its mangrove forests, marking the distinction between land and sea and forming a buffer zone between sea and shore. Along the coastal area of East-Java the mangrove forests form a unique ecosystem for marine species. The breeding and nursery grounds provided by the sheltered mangrove habitat directly relate to a productive source of economic benefits in sectors such as traditional fishery and aquaculture [3].

A common used program in shoreline change studies is the ArcGIS extension Digital Shoreline Analysis System (DSAS). The software program is used in both past shoreline changes [4] and in future prediction studies [5]. The main objective of this research is to determine the change in shoreline positions between 2006 and 2015 using DSAS as well as to identify erosion and accretion.

\section{Theoretical background}

\subsection{Coastal Zone}

The coastal zone is defined as the interface between the lithosphere, hydrosphere and atmosphere. It is a highly dynamic environment where physical processes play an important role in the development of the coast [6]. Geomorphological processes influencing the shaping of the coastal zone include the following:

- Waves are fluctuations on a water surface due to wind action. Within the coastal zone deep water regions change into shallow shore profiles where wave characteristics transform in height, speed and direction. The influence on coastal forms, whether changes will result in a movement seaward or landward, depends on the angle of the waves in comparison to the shore [7].

- Currents are the large masses of water moving in a specific direction. The movement is the result of differences in density, temperature and salinity of water between different locations [8]. The effect currents have on coastal morphology is little, except where warmer or colder water is brought; this changes ecological conditions which then influences shore dynamics [1].

- The tide is defined as the periodic rises and falls of large water bodies. Tidal influence is caused by the gravitational attraction between the Earth and the Moon. Contributing to the dispersion of sediments; the rising tides spread the sediment near the shore, whereas the falling of the tides contribute to erosion when sediments are taken away [1].

- Anthropogenic processes are caused due to human activities and occur in addition to natural forces. Rural populations have traditionally used mangrove trees to produce charcoal, fuelwood, boats and fish-traps. The main causes of loss of mangrove area have been overexploitation in combination with the development of shrimp farms. This results in serious human pressure on the ecosystem. When human activities increase the capability of mangrove forests to act as a natural buffer zone decreases, exposing the coastal zone to a greater vulnerability [9].

- Abrasion and accretion are the result of nearshore processes including beach morphology, wave climate, geology and human activities. The definition of accretion as stated by Thomas and Goudie [10] is the gradual increase in the area of land as a result of sedimentation. Erosion is defined as a group of processes whereby debris or 
rock material is loosened or dissolved [10]. A dynamic equilibrium is reached when accretion and erosion are balanced, resulting in minimal changes [11].

- Sea level rise: in addition to manmade pressures, the Intergovernmental Panel on Climate Change (IPCC) forecasts a global rise in sea level, effecting mangrove forests worldwide [12]. The supply of sediments will determine the ability of mangroves to keep up with the rise in sea level, which indicates the vulnerability of that area [13].

\subsection{Shoreline change}

The boundary between land and sea, defined as the shoreline, changes variably due to multiple factors, which may be morphological, climatological or geological in nature. The geometry depends on the interactions between and among winds, waves, currents, and tides. The interactions vary locally, resulting in differences in erosion and accretion rates. The sedimentation process taking place causes the shoreline to move seaward. On the contrary, the process of erosion causes the shoreline to move landwards [14].

\subsection{Mangrove area}

Mangrove trees are defined as woody vegetation capable of growing in the intertidal zone along tropical and subtropical coasts. Their root structures have the ability of slowing down the process of erosion process by holding on the sediment particles. In addition, allowing the process of accretion to continue [15]. Because of this ability mangroves are used in afforestation programs where trees are planted in vulnerable, eroded areas to protect the coastal zone with a natural process [16].

\subsection{Digital Shoreline Analysis System (DSAS)}

Shoreline analyzation is done by using Digital Shoreline Analysis System (DSAS). This Arc Map extension, developed by US Geological Survey (USGS) is publicly available and can be downloaded at http://woodshole.er.usgs.gov/project-pages/dsas/.

Provided by the program, four methods were used as data analysis, including the SCE, NSM, EPR and LRR $[17,18]$.

\section{Methodology}

\subsection{Literature study}

To understand and analyse the problems stated in this research a literature study was performed. Background knowledge was gained from various scientific material, including journals, articles, books and internet websites.

\subsection{Data collection}

Data sets used in this research are as follows: 
1. LANDSAT 7 satellite image data of the East-Java region with a resolution of 30 meters x 30 meters dated from 2006 to 2011 .

2. LANDSAT 8 satellite image data of the East-Java region with a resolution of 30 meters x 30 meters dated from 2012 until 2015.

\subsection{Data analysis}

In this study, Digital Shoreline Analysis System (DSAS) is used to calculate change rates. A shoreline change estimation is obtained using two different kinds of statistical approaches: distance and rate. The Shoreline Change Envelope (SCE) and Net Shoreline Movement (NSM) represent the distance while the End Point Rate (EPR) and Linear Regression Rate represent the rate of shoreline change. SCE is the distance between the shoreline furthest from and closest to the baseline at each transect. It represents the total change in shoreline movement for all shoreline positions. NSM reports the distance between the earliest and most recent shoreline for each transect. It represents the total distance. EPR is calculated by determining the distance between the oldest and most recent shoreline in the data and dividing it by the number of years between them. This method provides the net rate of change over the long term. LRR is calculated using least squares regression lines from all shoreline positions along transect. It is generally used to express shoreline movement and the estimation of change rate.

\section{Results and discussion}

\subsection{Results in shoreline change}

In this research, the shorelines were extracted from Landsat multi-temporal satellite images every year from 2006 until 2015. The imagery was digitized and analysed using software programs ArcGIS and DSAS. To determine the shoreline changes a baseline was established with a buffer of 200 meters both seaward and landward parallel to the general shoreline orientation. As a second step, 1429 transect lines were set with a length of 12 $\mathrm{km}$ and 25 meter of space in between transect lines. With these settings the statistical methods SCE, NSM, EPR and LRR were calculated. The results of the statistical methods, calculated by DSAS are summarized in Table 1.

Table 1. Data collection of DSAS statistical methods.

\begin{tabular}{lrccc}
\hline Subject & SCE $(\mathrm{m})$ & NSM $(\mathrm{m})$ & EPR $(\mathrm{m} / \mathrm{y})$ & LRR $(\mathrm{m} / \mathrm{y})$ \\
\hline Mean & 165.53 & 30.89 & 3.43 & 5.47 \\
Minimum & 0 & -928.75 & -99.3 & -129.53 \\
Maximum & 991.57 & 991.57 & 169.98 & 189.58 \\
& & & & \\
\hline
\end{tabular}

The detailed results are visualised in ArcGIS maps for the four statistical methods SCE, NSM, EPR and LRR. Five colour variations present the classified differences in erosion 
and accretion rates. The minimum value is shown in red and displays the most severe erosion as the green colour displays the maximum value: the highest rate of accretion. In between classes represent moderate erosion, neutral processes and moderate accretion with colours orange, yellow and light green. To prevent misinterpretation the choice of colour is chosen equally for all four statistical methods as viewed in Figures 1-4.
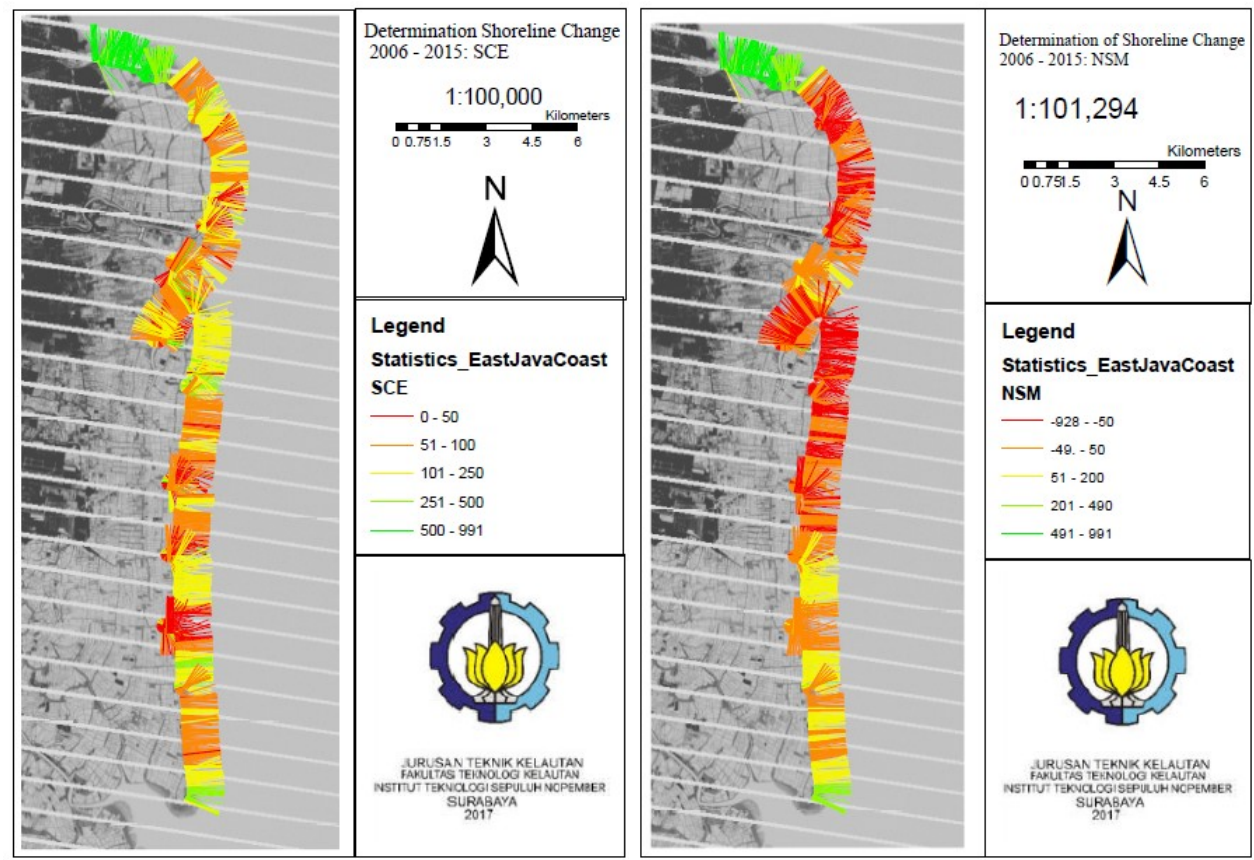

Fig. 1.(left) and Fig. 2. (right) Results of the Statistical methods SCE and NSM presented in an ArcGIS map.

The SCE value in Figure 1 represents the distance between the shoreline furthest from and closest to the baseline. Due to the extent of the study area and variations along the coastal areas, the shorelines defined as furthest from and closest to the baseline vary for each transect. The map shows a maximum distance of 991.57 meter, defining this as a maximum of accretion. The total distance in erosion and accretion in the period 20062015 is represented by the NSM value shown in Figure 2 The maximum erosion is -928.75 meter located in the Sedati district. The maximum accretion of 991.57 meter is located in the area of Mulyorejo.

The EPR analysis represents the speed of accretion and erosion in meter per year. Figure 3 presents the maximum accretion rate reaching 169.98 meter / year, while erosion rates reach a maximum of - 99.3 meter / year.

Figure 4 shows the LRR value expressing shoreline movement along the transect lines. With the Linear Regression Rate method, all shoreline positions are taking into account showing a maximum erosion rate of -129.53 meters between 2006 and 2015 as well as a maximum accretion rate of 189.58 meters. 


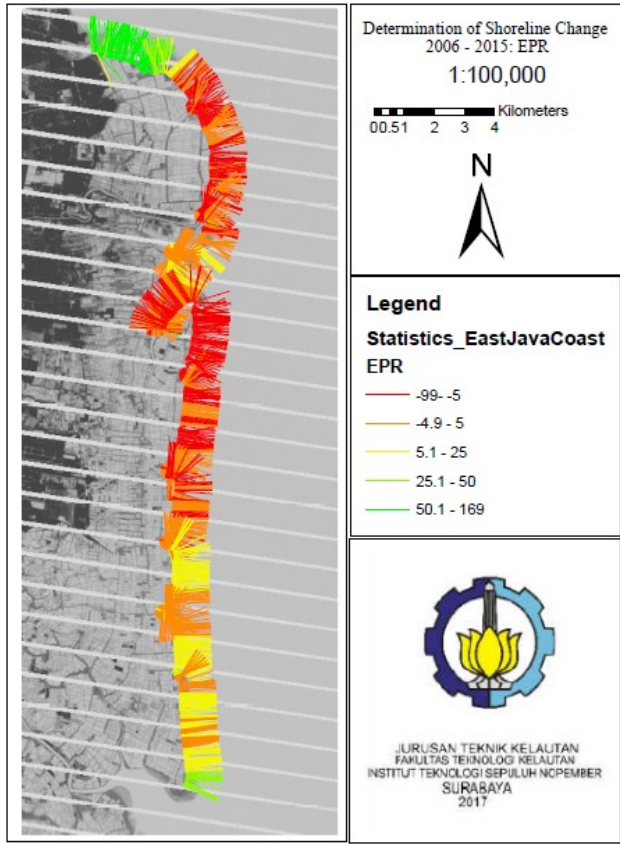

Fig. 3. Results of the Statistical method EPR presented in an ArcGIS map.

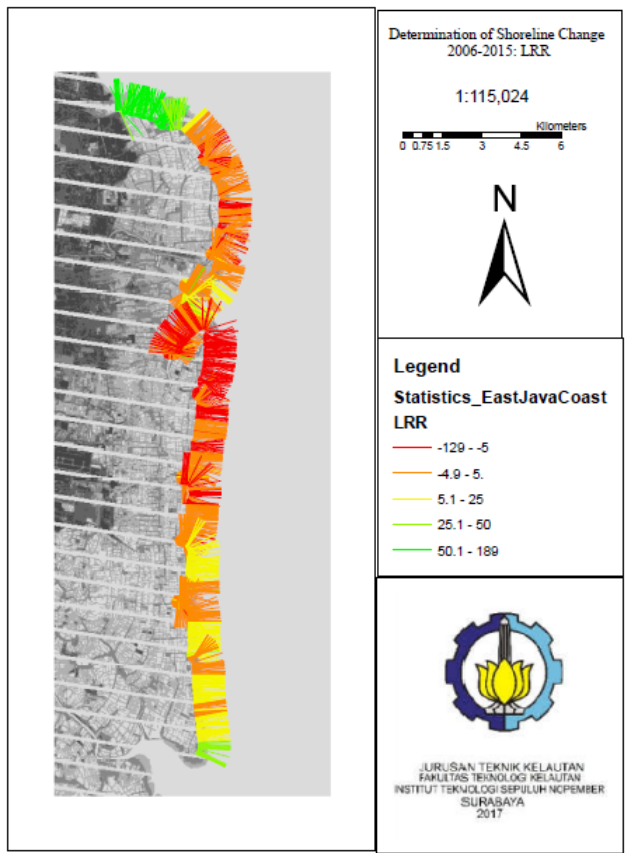

Fig. 4. Results of the Statistical method LRR presented in an ArcGIS map. 


\subsection{Discussion}

In this study, the value of uncertainty needs to be considered when calculating shoreline change using DSAS. With the uncertainty value, natural and anthropogenic forces are taken into account (wind, wave, tidal, current, human influence) as well as the accuracy of measurement (digitation, interpretation, global positioning system error). Establishing a value of uncertainty is done by selecting a Confidential Interval of $95 \%$ as well as a shoreline uncertainty value of 5 meters. Special attention needs to be given to the tidal influence on the Landsat satellite images. It is taken into consideration that the shorelines may differ at different moments in time, due to the change in water level. Even though, because of the large extend of the study area, the tidal difference would only be visible to an inconsiderable amount. The possible fluctuations caused by the change in water level is taken into account in the uncertainty factor. Furthermore, the misinterpretation of the shoreline part of the uncertainty factor. The edge pixels are, when zoomed in, of insufficient quality for shoreline extraction increasing the chance of mistakes in characterization.

\section{Conclusion}

Results based on analysation and discussion show the differences in erosion and accretion rates. The ArcGIS maps for the SCE, NSM, EPR and LRR present local differences varying from severe erosion, moderate erosion, neutral, moderate accretion till severe accretion. Statistical methods EPR and LRR representing the rate show a continuous process of erosion or accretion over the study period. With continuing rates the maximum erosion and accretion distance (SCE and NSM) could likely increase in a linear way in the future.

\section{Acknowledgements}

The author shows her gratitude to Institut Teknologi Sepuluh Nopember (ITS) Surabaya, Indonesia and HZ University of Applied Sciences Vlissingen, the Netherlands, including lecturers, researchers and students for the contribution to the research and development in education. Special thanks is given to internship in-company supervisor Dr. Suntoyo, for giving the opportunity to present at ISOCEEN seminar. 


\section{References}

1. E. C. Bird, Coastal Geomorphology: an Introduction, (2011)

2. S. Sukardjo, Integrated Coastal Zone Management (ICZM) in Indonesia, Japanese of Southeast Asian Studies, 40.2, 200-218, (2002)

3. P. K. Asokan, Mangroves and its importance to Fisheries, (2012)

4. M. I. Joesidawati, Suntoyo, Shoreline change in Tuban district, East Java using geospatial and Digital Shoreline Analysis System (DSAS) techniques, International Journal of Oceans and Oceanography, 235-246, (2016)

5. N. K. Barman, S. Chatterjee, A. Khan, Trends of Shoreline Position: An Approach to Future Prediction for Balasore Shoreline, Odisha, India, Open Journal of Marine Science, 5, 13-25, (2015)

6. I. P. Joliffe, Coastal erosion, environmental - geological hazard, Beaches and Coastal Geology, 267-271, (1982)

7. E. Barthélemy, Nonlinear shallow water theories for coastal waves, Surveys in Geophysics, 25, 315-337, (2004)

8. H. J. Verhagen, Aandrijfmechanisme voor Kuststromen, (1985)

9. FAO, The world's mangroves 1980-2005, (2007)

10. S. G. Thomas, A. Goudie, The Dictionary of Physical Geography, (2000)

11. H. Winterwerp, B. van Wesenbeeck, J. van Dalfsen, F. Tonneijck, A. Astra, S. Verschure, P. A. van Eijk, A sustainable solution for massive coastal erosion in Central Java, 45, (2014)

12. J. T. Houghten, Y. D. J. G. Ding, D. J. Griggs, M. Noguer, P. J. van der Linden, X. Dai, C. A. Johnson, Climate change 2001: the scientific basis, (2001)

13. J. C. Ellison, D. R. Stoddart, Mangrove ecosystem collapse during predicted sea-level rise: Holocene analogues and implications and implications, Journal of Coastal research, 151-165, (1991)

14. V. D. Prasita, Determination of shoreline changes from 2002 to 2014 in The Mangrove Conservation Areas of Pamurbaya using GIS, Procedia Earth and Planetary Science, 14, 25-32, (2015)

15. W. Giesen, S. Wulffraat, M. Zieren, L. Scholten, Mangrove guidebook for Southeast Asia, Mangrove guidebook for Southeast Asia, (2007)

16. F. Blasco, P. Saenger, E. Janodet, Mangroves as indicators of coastal change, Catena, 27, 167-178, (1996)

17. E. A. Himmelstoss, DSAS 4.0 Installation Instructions and User Guide, (2009)

18. J. L. Zichichi, A. Ergul, Digital Shoreline Analysis System (DSAS) version 4.0 - An ArcGIS extension for calculating shoreline change: U.S. Geological Survey OpenFile Report 2008-1278 